\title{
PERANCANGAN APLIKASI MONITORING INVENTORY PADA CV MAJORBEE TEKNOLOGI INDONESIA BERBASIS JAVA NETBEANS
}

\author{
Cilvia Nur'Aini ${ }^{1}$, Ambar Tri Hapsari ${ }^{2}$, Hendro Purwoko ${ }^{3}$ \\ Program Studi Teknik Informatika, Fakultas Teknik dan Ilmu Komputer, \\ Universitas Indraprasta PGRI \\ Jalan Raya Tengah No 80, Kelurahan Gedong, Pasar Rebo, Jakarta Timur \\ Cilvianurani20@gmail.com¹, ambar.trihapsari@gmail.com², hendroprwk08@gmail.com³
}

\begin{abstract}
Abstrak
Dukungan teknologi menjadi alat bantu yang paling digunakan dalam aktivitas manusia, hal ini tidak lepas dari keterbatasan manusia. Oleh sebab itu, banyak perusahaan yang beralih dari sistem manual menjadi sistem yang terkomputerisasi. CV Majorbee Teknologi Indonesia memiliki proses barang masuk dan permintaan masih menggunakan sistem manual berupa arsip, selain itu pengecekan stok barang digudang juga masih harus mengecek satu persatu disesuaikan dengan arsip sehingga membutuhkan waktu yang lama dan ketelitian yang tinggi. Tujuan dari penelitian ini adalah Membuat apl ikasi monitoring inventory pada CV Majorbee Teknologi Indonesia agar monitoring inventory lebih efektif dan efisien, mempermudah dalam mengelola barang masuk, data permintaan dan stok barang agar lebih cepat, tepat, dan akurat. Peneliti melakukan penelitian dengan metode grounded research berdasarkan pada fakta dan menggunakan analisis perbandingan bertujuan untuk mengadakan general empiris, menetapkan konsep-konsep, membuktikan teori dan mengembangkan teori di mana pengumpulan data dan analisa data berjalan pada waktu yang bersamaan.
\end{abstract}

Kata Kunci: perancangan, monitoring inventory, grounded research.

Abstract

Technological support becomes the most used tool in human activities, this cannot be separated from human limitations. Therefore, many companies are switching from manual systems to computerized systems. CV Majorbee Teknologi Indonesia has an entry goods process and demand still uses a manual system in the form of archives, in addition, checking the stock of goods in the field also still has to check one by one adjusted to the archive so that it takes a long time and high accuracy. The purpose of this research is to make the application of inventory monitoring on CV Majorbee Teknologi Indonesia so that inventory monitoring is more effective and efficient, making it easier to manage incoming goods, demand data and stock of goods to be faster, precise, and accurate. Researchers conduct research with grounded research methods based on facts and use comparative analysis aimed at conducting empirical generals, establishing concepts, proving theories and developing theories in which data collection and data analysis run at the same time.

Keyword: design, monitoring inventory, grounded research.

\section{PENDAHULUAN}

Perkembangan teknologi yang pesat dari waktu ke waktu membuat pekerjaan yang dilakukan manusia dapat diselesaikan dengan mudah, cepat dan efektif, namun pada satu sisi bisa terjadi sebaliknya hal ini tidak lepas dari keterbatasan manusia. Oleh sebab itu perusahaan perlu beralih dari sistem manual menjadi sistem yang terkomputerisasi. Monitoring adalah proses pengumpulan dan analisis informasi berdasarkan indikator yang di tetapkan secara sistematis dan kontinu tentang kegiatan program sehingga dapat dilakukan tindakan koreksi untuk penyempurnaan program atau kegiatan itu selanjutnya (Rahman, 2018) . CV Majorbee Teknologi Indonesia adalah suatu perusahaan nasional yang bekerja secara profesional, bergerak dalam bidang pengadaan bahan pangan, jasa, makanan, dan minuman. Perusahaan ini merupakan salah satu perusahaan yang semua proses kegiatan di dalamnya masih sistem manual. Perancangan adalah proses pengembangan spesifikasi baru berdasarkan rekomendasi hasil analisis sistem" (Prof.Dr.Sri Mulyani, 2017). Dalam perusahaan besar maupun kecil selalu ada proses inventory. Inventory adalah aset yang ada dalam bentuk barang-barang yang dimilki perusahaan. (Farhan, 2020). 
Jadi, dapat disimpulkan bahawa perancangan aplikasi monitoring inventory adalah suatu penentuan proses pengembangan yang di perlukan untuk dilakukan tindakan koreksi untuk penyempurnaan kegiatan dengan menggunakan software untuk mengerjakan tugas-tugas tertentu. Berdasarkan Permasalahan di atas penulis bermaksud melakukan perancangan aplikasi Monitoring Inventory pada CV Majorbee Teknologi Indonesia Berbasis Java Netbeans dengan metode grounded research. Tujuan dari penelitian ini adala agar aplikasi yang peneliti buat dapat membantu agar memonitoring inventory dalam berjalan denga lebih baik lagi cepat, tepat, dan akurat dengan waktu yang relevan. Sehingga memudahkan pengguna dalam menyimpan data dan aman terjaga tidak mudah hilang dan tidak ada nya kecurangan.

\section{PENELITIAN RELEVAN}

Dalam rangka mendapatkan hasil penelitian yang baik dan akurat, maka peneliti melakukan penelitian degan cara penelitian langsung dan juga studi pustaka, adapun beberapa hasil penelitian yang di jadikan acuan sebagai berikut :

Penelitian oleh Muhammad Farhan Tahun 2020, dengan judul Perancangan Sistem Inventori Dan Penjualan Pakaian di Konveksi Aulia Collection, Hasil Penelitian adalah Komputerisasi sistem penjualan pada konveksi Aulia Collection

Penelitian oleh Redo Abeputra Sihombing Tahun 2021,dengan judul: Rancangan Sistem Aplikasi Inventory Pada Pondok Pesantren SMP Asshaburatib Almadhani Berbasis Java Netbeans, Hasil Penelitian adalah Proses rekap data, laporan-laporan agar menjadi lebih efektif dan efisien.

\section{METODE PENELITIAN}

Penulis melakukan penelitian dengan metode grounded research. Grounded research adalah metode penelitian berdasarkan pada fakta dan menggunakan analisis perbandingan bertujuan untuk mengadakan general empiris, menetapkan konsep-konsep, membuktikan teori dan mengembangkan teori di mana pengumpulan data dan analisa data berjalan pada waktu yang bersamaan (Sugiyono, 2011). Berikut Pengembangan yang dilakukan penulis adalah sebagai berikut :

\section{Observasi ( pengamatan )}

Observasi yang dilakukan adalah mempelajari dan mengamati sistem kerja yang berjalan sebelumnya di mana mencari titik permasalahan yang ada. Penulis melakukan observasi mengenai proses Monitoring Inventory agar Penulis dapat menemukan fakta fakta yang ada dan kemungkinan yang akan terjadi di sesuai fakta yang ada. Penulis juga melakukan observasi secara keseluruhan hingga pengujian hasil aplikasi program:

\section{Wawancara}

Wawancara dilakukan untuk menemukan permasalahan yang ada dab penjelasan langsung dari pihak perusahaan mengenai kondisi dan kegiatan yang berlangsung. Wawancara penulis lakukan untuk memperkuat hasil dari observasi yang penulis lakukan.

\section{Perancangan Sistem}

Setelah melakukan analisa melalui wawancara dan observasi, maka langkah selanjutnya adalah membuat perancangan sistem. Perancangan sistem ini dilakukan untuk membuat gambaran umum mengenai proses sistem yang akan dibuat agar sesuai dengan yang dibutuhkan untuk ditujukan kepada pengguna agar dapat memahami proses sistem tersebut. Hasil output dari perancangan sistem ini adalah berupa laporan-laporan. Laporan tersebut yaitu laporan barang masuk yang berisi data-data barang masuk, laporan pembelian yang berisi data-data pembelian, laporan stok barang yang berisi data stok barang yang ada digudang, laporan data supplier yang berisi data-data supplier, dan laporan pengiriman yang berisi laporan data pembelian yang sudah dikirim.

\section{Pembuatan Database}

Setelah melakukan perancangan sistem maka langkah selanjutnya adalah membuat database. Pembuatan database ini dilakukan untuk menyimpan data-data dalam bentuk file yang saling terhubung dan tersimpan di dalam media penyimpanan dengan tujuan agar kualitas aplikasi memberikan informasi yang akurat pada waktu yang relevan seta mengurangi duplikasi suatu data dan mengurangi pemborosan tempat penyimpanan, serta dapat mengaman data agar tidak hilang.

\section{Coding}


Selanjutnya peneliti melakukan pengkodean atau coding yaitu menerjemahkan langkah-langkah yang sudah di buat kedalam bahasa komputer. Pada aplikasi ini bahasa pemograman yang digunakan adalah Java Netbeans.

\section{Pengujian}

Setelah semua langkah selesai maka langkah selanjutnya peneliti melakukan pengujian. Pengujian dilakukan untuk mengetahui apakah aplikasi yang dibuat sudah benar dan sesuai dengan apa yang sudah di analisa dan dibutuhkan. Jika Sudah sesuai maka melakukan penerapan dan jika masih terjadi eror maka dilakukan pembenaran lagi.

\section{Penerapan dan pemeliharaan}

Jika aplikais sudah berhasil maka langkah selanjutnya adalah proses penerapan dan pemelihraan dimana aplikasi ini harus di lakukan pemeliharaan dengan mengupdate aplikasi kembali jika terjadi perubahan sistem.

\section{HASIL DAN PEMBAHASAN}

\section{Analisa Permasalahan}

Sistem monitoring inventory yang sudah ada memang cukup baik, namun masih ada beberapa kekurangan berikut antara lain :

1. Data dilakukan masih secara manual berupa arsip sehingga membutuhkan waktu cukup lama.

2. Proses pencatatan secara manual memerlukan tempat penyimpanan yang luas, akibatnya kertas menumpuk serta memerlukan waktu yang lama dalam pencarian data kembali.

3. Sering hilangnya laporan-laporan sehingga tidak memiliki cadangan laporan.

4. Sistem monitorinng inventory yang kurang baik, sehingga mempengaruhi sistem yang lainnya.

\section{Alternatif Penyelesaian Masalah}

Untuk mendapatkan solusi permasalahan yang ada maka penulis membuat suatu sistem yang akan membantu dalam menyelesaikan masalah tersebut, yaitu aplikasi monitoring inventory yang akan memudahkan dalam pengolahan data :

1. Bagaimana cara monitoring inventory pada CV Majorbee Teknologi Indonesia agar lebih efektif dan efisien?

2. Bagaimana mengelola barang masuk, data permintaan, dan stok barang agar lebih cepat, tepat, akurat dan mudah dalam menyimpan data?

3. Bagaimana membuat laporan agar lebih akurat dan memiliki bukti jika terjadi kehilangan.

\section{Alur Sistem Berjalan}

Alur sistem yang ada disini adalah bagian Admin melakukan penginputan data barang masuk di form barang masuk pada saat ada barang yang masuk ke gudang selanjutnya jika supplier tersebut belum terdaftar atau masih supplier yang baru beragabung maka langkah selanjutnya adalah menginput data supplier. Langkah selanjutnya Jika terjadi pembelian maka otomatis admin mengisi form pembelian dimana form pembelian tersebut akan terhubung ke form pembayaran. Jika konsumen sudah membayar maka admin mengupdate data di form pembayaran agar otomatis masuk ke form pengiriman. Selanjutnya bagian gudang mengupdate data pengiriman yang tadinya belum terkirim sudah menjadi terkirim jika sudah dilakukan pengiriman oleh gudang. Sehingga semua barang yang masuk dan data pembelian akan otomatis terhubunng oleh stok barang diamana jika terjadi pembelian maka stok barang kan berkurang dan jika terjadi barang masuk maka stok barang akan bertambah. Jika suatu saat dibutuhkan laporan maka admin dapat mengklik tombol laporan dimana admin dapat memilih laporan yang diinginkan sehingga laporan akan otomatis di tampilkan. 


\section{Diagram Konteks}

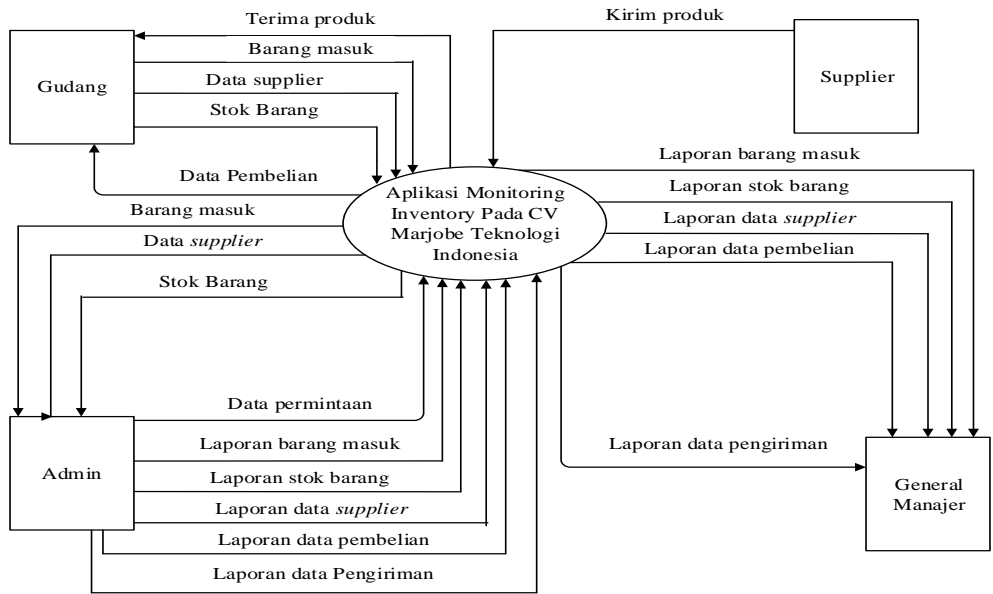

Gambar 1. Tampilan Diagram Alir Data

\section{Entity Relationship Diagrm (ERD)}

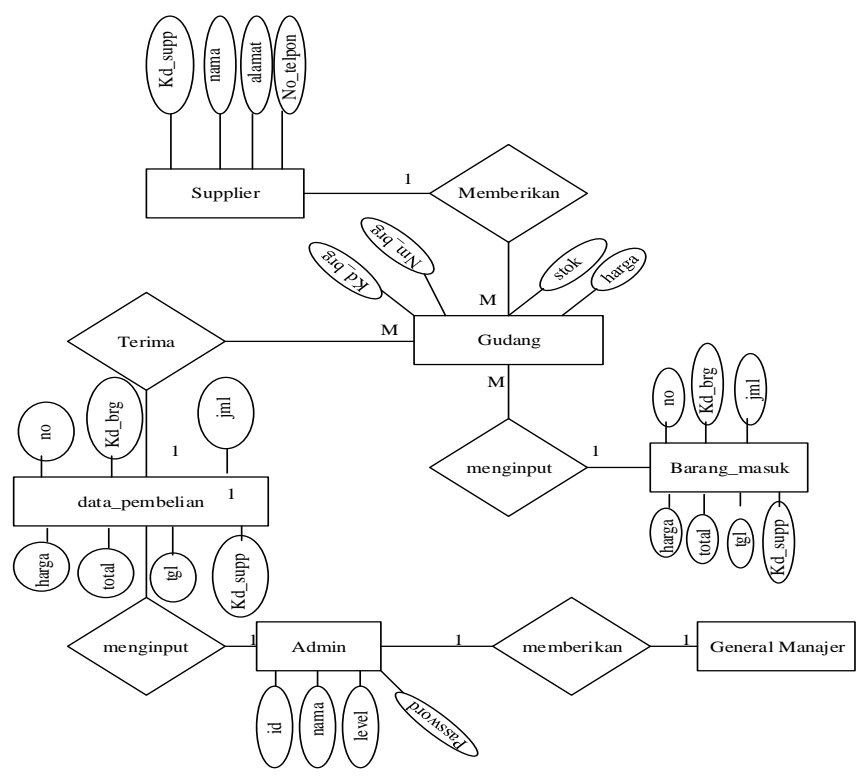

Gambar 2. Entity Relationship Diagram

\section{Rancangan Layar, Rancangan Form Masukan, Dan Rancangan Keluaran}
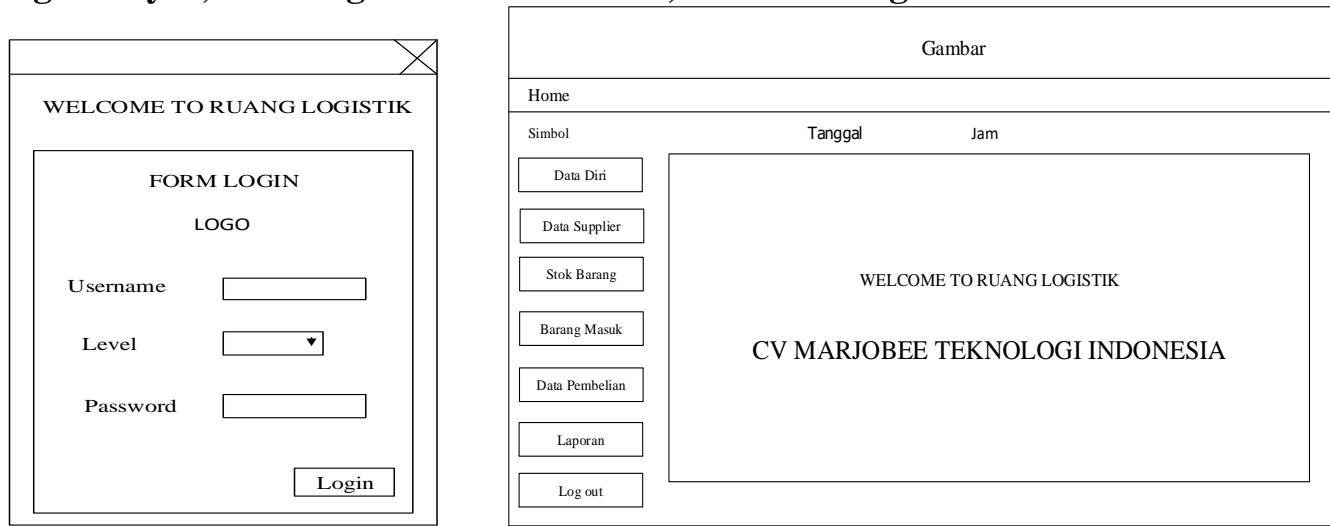

Gambar 3. Rancangan Menu Login dan Rancangan Beranda 

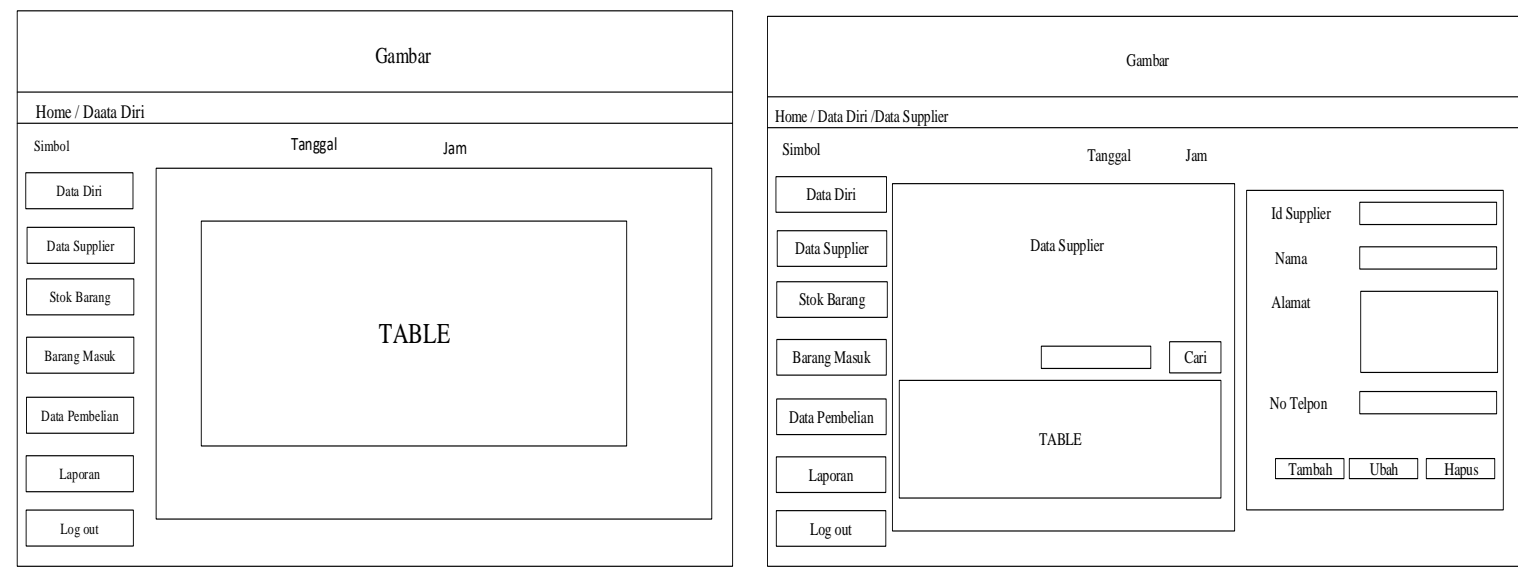

Gambar 4. Rancangan Data Diri dan Rancangan Data Supplier
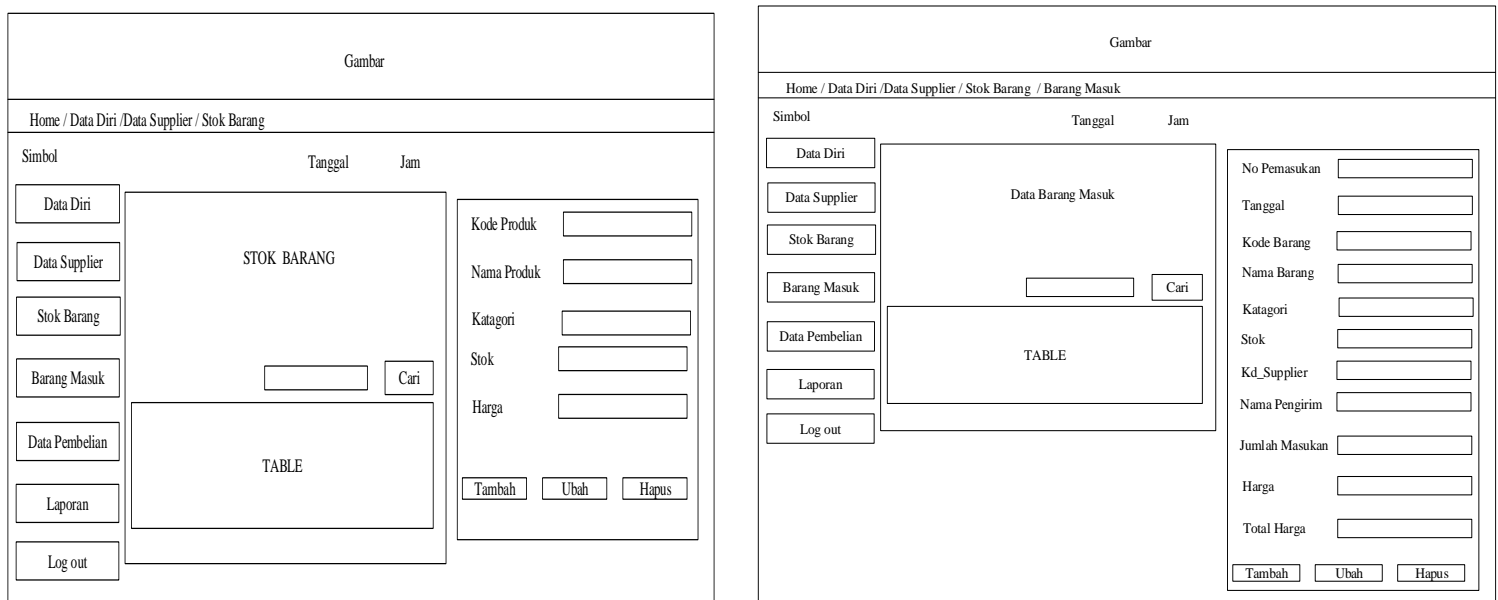

Gambar 5. Rancangan Stok Barang dan Rancangan Barang Masuk
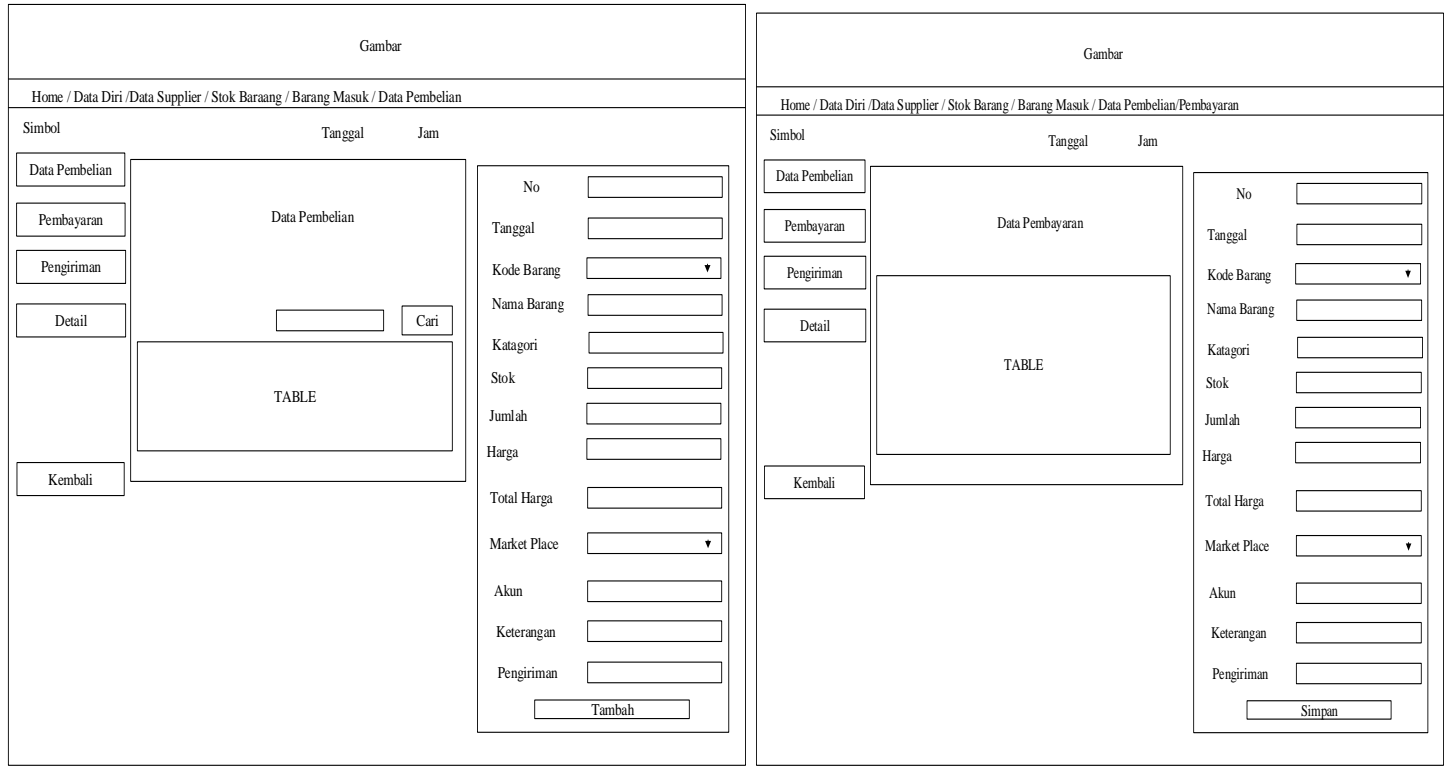

Gambar 6. Rancangan Data Pembelian dan Rancangan Data Pembayaran 


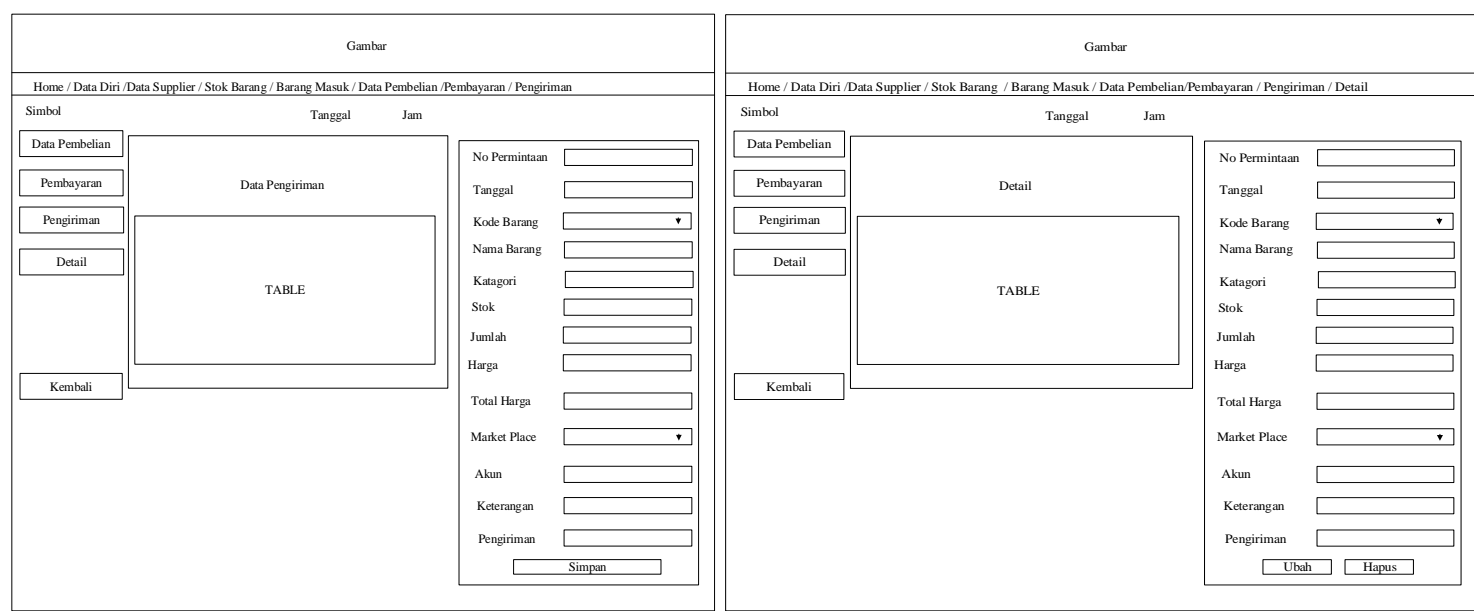

Gambar 7. Rancangan Data Pengiriman dan Rancangan Data Detail

\section{Interface}
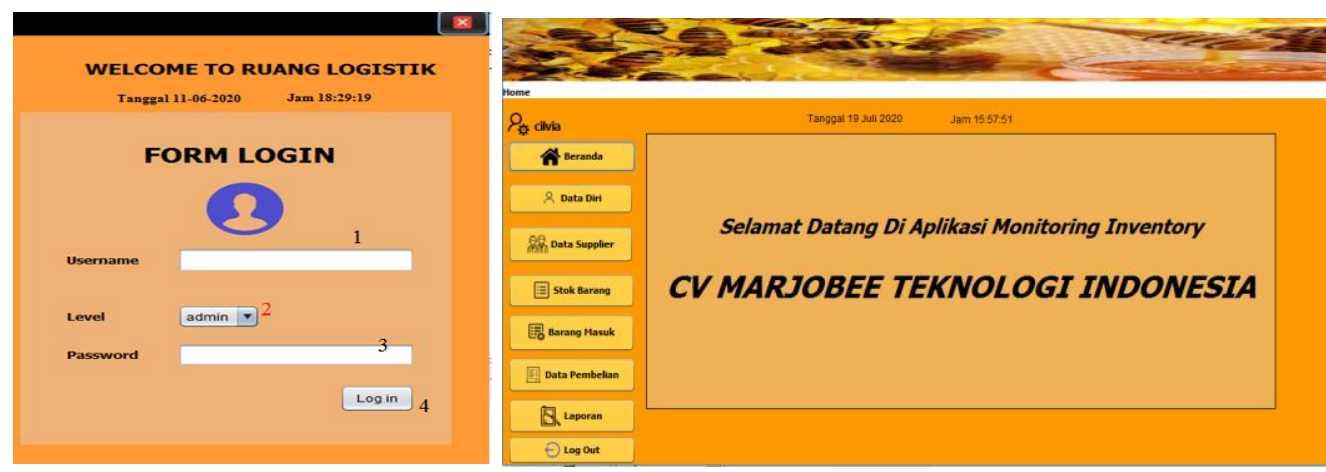

Gambar 8. Tampilan Menu Login dan Tampilan Menu Beranda

Menu Login adalah menu untuk masuk ke aplikasi monitoring inventory. Masukan username, level, dan password Anda untuk dapat masuk ke aplikasi. Menu utama adalah menu awal setelah melakukan login. Menu utama terdiri dari beberapa menu yaitu Beranda, Data Diri, Data Supplier, Stok Barang, Barang Masuk, Data Pembelian, Laporan, dan Log out.
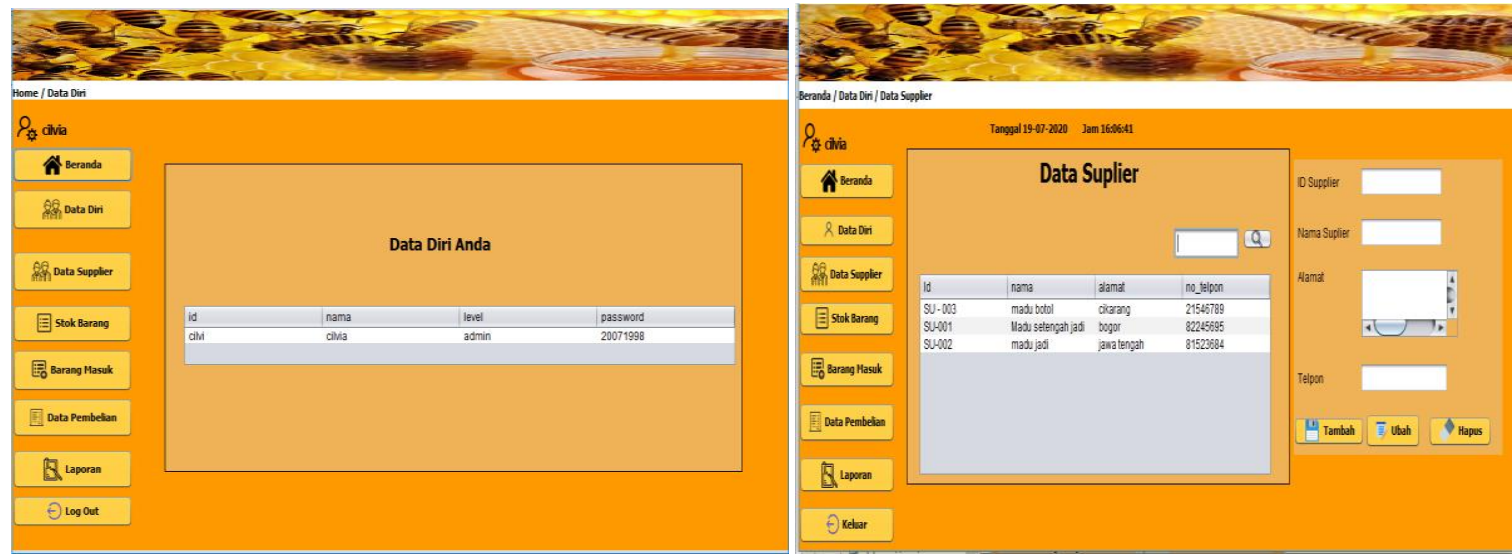

Gambar 9. Tampilan Data Diri dan Tampilan Data Supplier

Menu data diri adalah tampilan menu yang berisi data diri yang login yang di dalamnya kan ditampilkan nama, username, level, password. Sehingga, data diri user terlihat di dalam tabel itu. Menu Data Supplier adalah menu yang berisi data-data supplier di mana data supplier dapat ditambah, diubah dan dihapus. Data Supplier terdiri dari kd supplier, nama supplier, alamat, no telepon. 


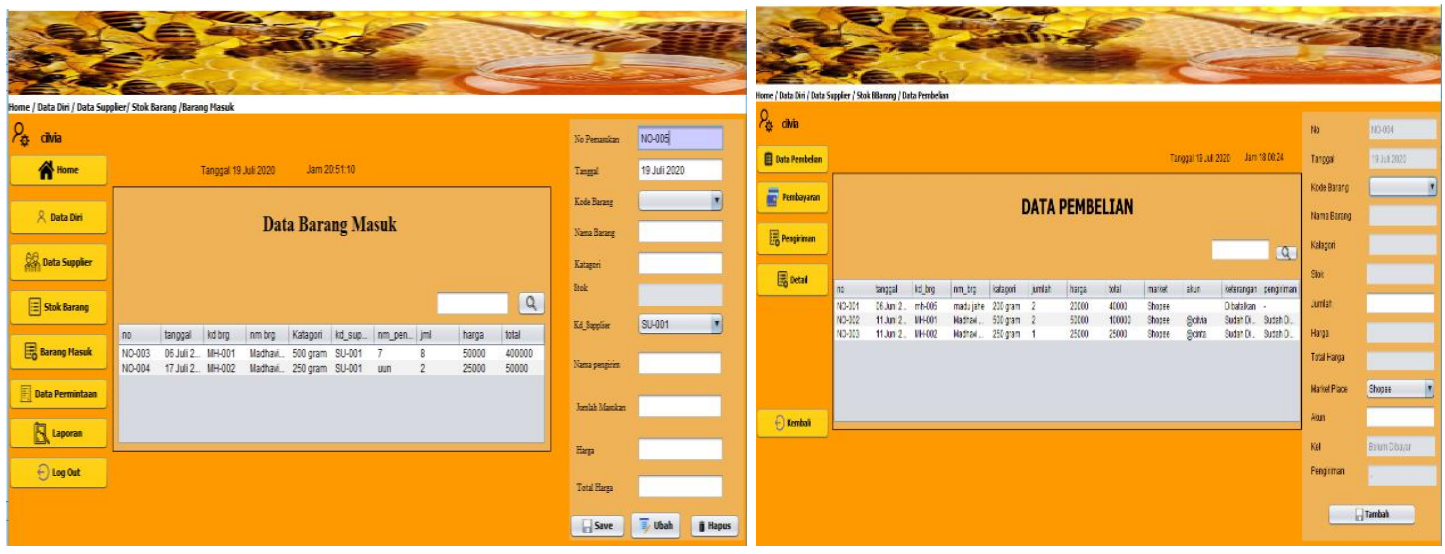

Gambar 10 . Barang Masuk dan Data Pembelian

Menu Barang Masuk adalah menu yang berisi data-data ketika terjadinya barang yang masuk. User dapat mengisi data-data barang masuk dan dapat menyimpan, mengubah, serta menghapus datadata barang masuk. Menu Data Pembelian adalah menu yang berisi data data-data mengenai pembelian dimana di dalam menu data pemintaan terdapat sub menu yaitu pembayaran, pengiriman, dan detail. Di dalam menu pembelian user dapat menginput data yang telah melakukan pembelian.
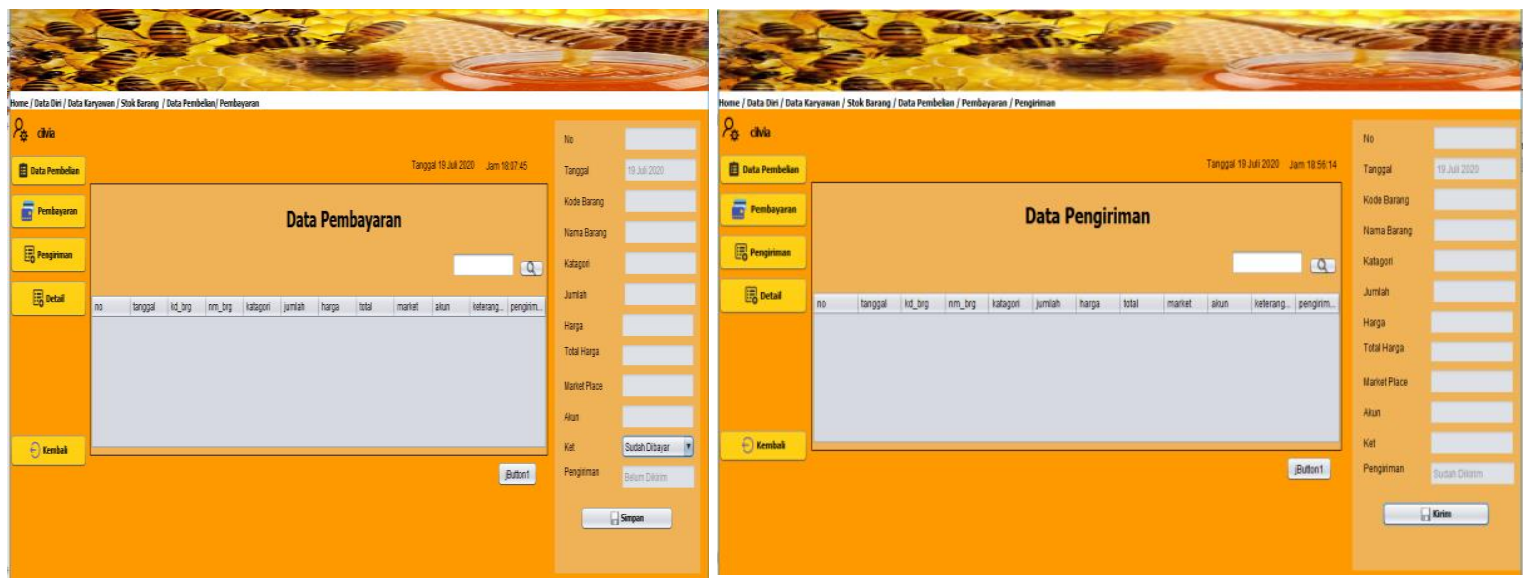

Gambar 11. Data Pembayaran dan Data Pengiriman

Menu Pembayaran adalah menu yang berisi permintaan yang belum melakukan pembayaran. Ketika konsumen sudah melakukan pembayaran maka user akan mengedit di form Pembayaran bahwa konsumen sudah melakukan pembayaran di mana dalam tabel pembayaran akan otomatis hilang dan ter-update ke data pengiriman. Setelah melakukan pembayaran maka user akan masuk ke menu pengiriman di mana user akan mengubah data dari kosong menjadi sudah terkirim.
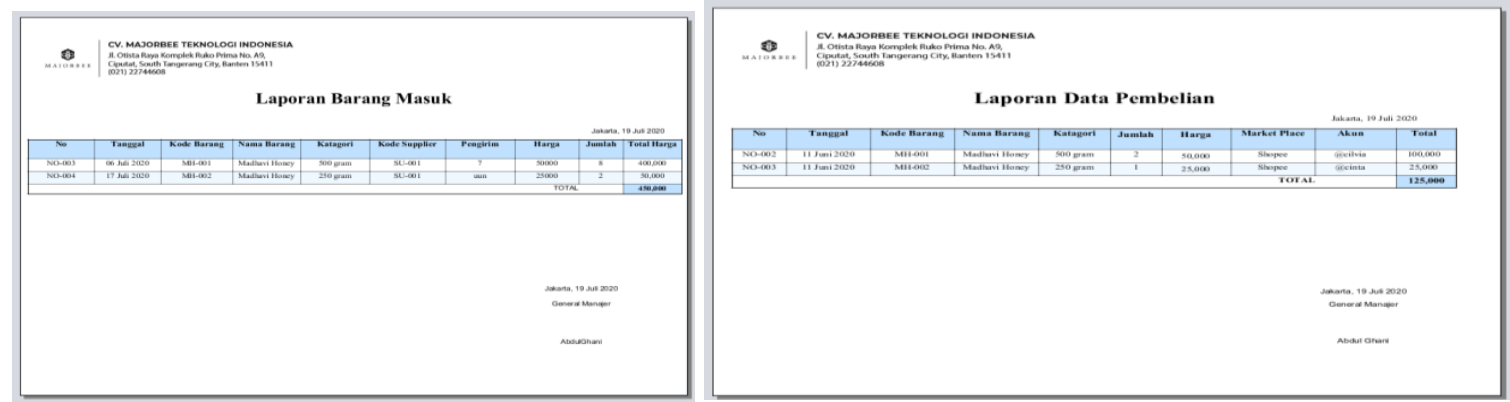

Gambar 12. Laporan Barang Masuk dan Laporan Data Pembelian 
Laporan Barang Masuk adalah seluruh laporan data-data barang yang masuk sehingga user dapat memberitahu biaya yang harus dikeluarkan saat barang masuk. Laporan Pengiriman adalah laporan data-data yang sudah dikirim sehingga sebagai bukti pengiriman.

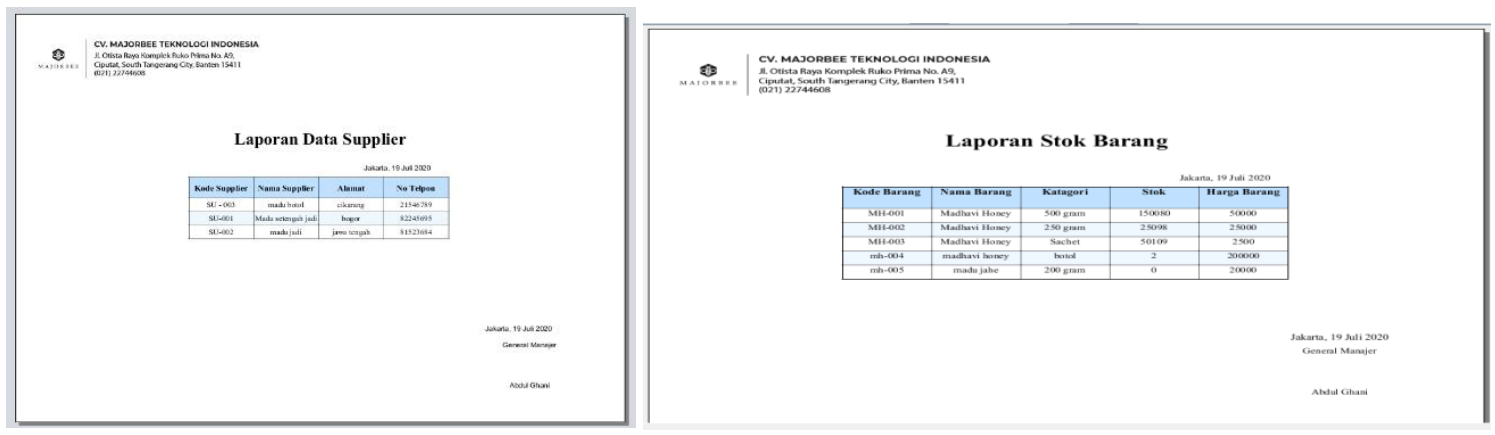

Gambar 13 . Laporan Data Supplier dan Laporan Stok Barang

Laporan data supplier adalah laporan mengenai supplier seperti kode supplier alamat, nomor telepon. Laporan stok barang adalah laporan di mana stok barang dapat diketahui untuk memonitoring stok yang tersisa.

\section{SIMPULAN}

1. Dengan adanya aplikasi monitoring inventory ini maka sistem yang berjalan sudah terkomputerisasi secara otomatis, sehingga dapat mempermudah pengelolaan stok barang dan pembelian serta meningkatkan kinerja karyawan di dalam perusahaan.

2. Dengan dibangunnya aplikasi monitoring inventory, maka kendala yang semula dihadapi oleh pihak CV Majorbee Teknologi Indonesia, yaitu ketepatan waktu dalam pencarian stok barang, proses pembelian maupun barang masuk dapat di tangani dengan tepat cepat dan akurat .

3. Aplikasi ini dapat membantu admin untuk mempercepat proses pembuatan laporan data-data permintaan, barang masuk, stok barang, dan pengiriman kepada general manajer dengan lebih mudah dan rinci dalam setiap periode tertentu.

\section{DAFTAR PUSTAKA}

Farhan, M. (2020). Perancangan Sistem Inventory dan Penjualan pakaian di konveksi Aulia Collection. Jurnal Riset dan Aplikasi Mahasiswa Informatika.

Hendro Purwoko, S. M. (2017). Rancang Bangun Sistem Informasi Gudang Obat dan Alat Kesehatan berbasis Dekstop dengan Menggunakan Microsoft Access pada RSU Islam Madinah Kasembon Malang. The 6th University Research Colloquium, 87-90.

Jogiyanto. (2010). Analisis Dan Desain Sistem Informasi. Yogyakarta: Andi Offset.

Pratiwi. (2020 ). Perancangan Aplikasi Inventory Barang pada Kartika Graha Indonesia Berbasis Java Netbeans. Jurnal Riset dan Aplikasi Mahasiswa Informatika.

Pressman, R. (2012). Rekayasa Perangkat Lunak: Pendekatan praktisi ( 7.ed). Yogyakarta: andi Publisher.

Prof.Dr.Sri Mulyani, A. C. (2017). Metode Analisis dan Perancangan Sistem. Abdi Sistematika.

Rahman, A. (2018, Agustus ). Sistem Monitoring Piutang dan Inventori Barang. Technologia Jurnal Ilmiah, 04 No. 02, 142-149.

Sihombing, R. (2020). Perancangan Aplikasi Ivnetory Pada Pondok Pesantren SMP Asshaburatub Almadhani Berbasis Java Netbeans. Jurnal Riset Dan Aplikasi Mahasisw Informatika.

Subhan, M. (2012). Analisa Perancangan Sistem. Jakarta: Lentera Ilmu Cendekia.

Sugiyono. (2011). Metode Penelitian Kuantitatif, Kualitatif dan R\&D. Alfabeta. 